\title{
The Chronic Balance of Payments Constraint on Economic Growth in Turkey
}

\author{
ERTAN ERSOY \\ Istanbul University, Turkey
}

\begin{abstract}
This paper investigates Turkey's economic growth performance in the light of Thirlwall's Law (1979) for the period of 2003Q1-2015Q3. Initially, to strengthen its predictive power, the extended version of Thirlwall's Law (1982) has been modified further by incorporating the Net Earnings of Services and Investments (NESI). The empirical results attained through the proposed modification of Thirlwall's Law verify its predictive power. The evidence also shows that Turkey's poor Balance of Payments (BOP) performance is still a leading constraint on real GDP growth which could not exceed its historical average in this period. In addition, there is a growing tendency of the economy to finance its external deficit and economic growth with capital inflows which cannot be sustained in the long-run. In other words, despite receiving a substantial volume of foreign capital and accumulating a sizeable amount of foreign debt, Turkey could not solve its chronic BOP problems with appropriate economic policies in this period. Lastly, these findings indicate the end of the last boom-bust cycle of 2003-2015.
\end{abstract}

\section{Keywords}

economic growth, Thirlwall's Law, foreign trade, capital inflows

\section{Introduction}

As a consequence of the 1980s neoliberal transformation, Turkey's economy became one of the most open economies in the world. The ratio of total foreign trade to GDP was approximately $10 \%$ at the beginning of the 1980s and it reached 50\% in 2015 through the export-led growth (ELG) policy. Although remaining almost the same for the following decades, the ratio of exports meeting imports increased from approximately $45 \%$ to $70 \%$ in the period of 1980-89, and it is approximately 72\% in the period 2003Q1-2015Q3. However, contrary to the ELG policy goal of sustainable and rapid economic growth without persistent external imbalances, Turkey could not reach a GDP growth rate higher than its long-term historical average. This weak economic structure resulted in severe economic crises in 1994, 1998, 2001 and 2008 which were mainly outcome of the contradicting tendencies of output growth and BOP performance. The slow GDP growth and poor BOP performance persisted during the period 2003-2015.

These observed facts suggest the need to address the relationship between external balance and economic growth which is modelled by post-Keynesian economist A.P Thirlwall. The original Thirlwall's Law (1979) asserts that the output growth rate of an economy is constrained by its balance of payments 
(BOP) performance. ${ }^{1}$ The basic hypothesis of this demand oriented model, under the necessity of the BOP equilibrium, is that the output growth of an open economy is determined by the ratio of the growth rate of exports to the income elasticity of demand for imports. With an implicit assumption that BOP only consists of imports and exports; a trade balance would be ensured at any time and any deviation from the equilibrium would be cleared by simultaneous adjustment of the output level.

This version of the model operated as a good predictor for countries that have balanced trade, yet it failed in the case of developing countries that have persistent trade deficits and offset them with foreign capital inflows. Acknowledging the weakness of the original model to detect the impact of capital flows to the BPCG, especially for developing countries, Thirlwall and Hussain (1982) incorporated the capital inflows as an additional independent variable into it.

However, the inclusion of the capital inflows should be considered necessary but not a sufficient modification to develop a well-constructed BPCG model. In other words, determining the BPCG rate of an economy through import capacity, which is provided by the sum of export earnings and capital inflows, will cause inaccurate results. The crucial point to stress here is the presence of the import capacity generating characteristic of some other components in the current account side of BOP. Indeed, Thirlwall underlined the fundamental position of import capacity by emphasising the importance of the level of exports as the only component that can provide foreign exchange to cover import expenditures (Thirlwall 1997: 380). Therefore, this paper proposes the NESI as a supplementary import capacity generating component to be inserted in the model and tests this version of the model for the Turkish economy.

In the following section a brief summary of related literature is presented with various extensions. In the third section, a mathematical illustration of previous versions and the NESI incorporated version are briefly presented with the disaggregation of exports and capital inflows within the model. In the fourth section, an empirical application that comprises the data generation process, the econometric model, and the application of appropriate econometric techniques are presented in detail. The fifth section introduces a brief assessment of econometric test results and computations of the estimated BPCG rates based on corresponding modifications with the

\footnotetext{
1 The role of external balance in economic growth is theorized firstly by R. Harrod (1933) and then modelled by A.P. Thirlwall (1979) in the Post-Keynesian tradition in the light of Verdoorn's (1949) and Kaldor's $(1966,1970)$ works.
} 
evolution of Turkey's BOP performance. The concluding section summarises the findings and their policy implications.

\section{Literature survey}

Ever since the original and extended versions of Thirlwall's Law were developed they have been tested widely with various modifications for both developed and developing countries. The original version of the model first tested by Thirlwall in the same paper mostly for developed European economies, including the USA and Canada for the periods 1951-73 and 195376, and the test results revealed remarkable support for the hypothesis (Thirlwall 1979: 434-5). Then Alonso $(1998,1999)$ tested this version of the model, firstly for a group of developed countries and then for Spain over the period 1960-94. Also, McCombie tested the original (1985) and extended version (1989), Ateşoğlu tested the original version for the USA (1993) and Germany (1995), the extended version for Canada (1993-94) and the empirical findings demonstrated the robustness of Thirlwall's Law. ${ }^{2}$

Yet in this article the main motivation is to test the NESI incorporated version of Thirlwall's Law for Turkey and to assess its economic growth experience in the light of test results for the period 2003Q1-2015Q3. Therefore, the empirical and theoretical survey focuses on the earlier studies that include Turkey. In this context Turkey's estimated elasticities and GDP growth rates are examined in detail in the scope of selected applications. The results are presented in Table 1.

Thirlwall and Hussain (1982) performed the first empirical test of the capital flows extended version using the data from 20 developing countries. In their study, in addition to their own estimation (including Turkey), they used two groups of countries' income elasticity of imports that were estimated by M. Khan (1974) for the period between 1951 and 1969, and by Houthakker and Magee (1969) for 1951-1966. The test results, in general, supported the predictive power of the capital flows extended version of Thirlwall's Law for developing countries. The findings for Turkey were similar to those of the other developing countries. The estimated average growth rates of Turkey for the period 1960-73, using the original and capital flows extended models, were $6.1 \%$ and $5.9 \%$, respectively, against the actual output growth rate of $5.8 \%$ (see Table 1 ). They put forward that the relative price movements, which

\footnotetext{
2 There are also criticisms made by Crafts (1988a, 1988b, 1993) based on the Balassa (1979) model, McGregor and Swales (1985, 1986, 1991) and Krugman (1989) which have been responded to persuasively by McCombie \& Thirlwall (1997).
} 
are neglected by the model, can account for the difference between the estimated and actual growth rates.

A group of scholars, Elliot and Rhodd (1999), Ferreira and Canuto (2003), Moreno-Brid (2003), Vera (2006) and Alleyne and Francis (2008), disregarded the role of relative price movements and instead pointed out the debtservicing payments. They argued that many developing countries finance their persistent current account deficits with foreign debt and, debt-servicing payments take a considerable portion in their BOP. Therefore, the growth of debt-servicing should be regarded as a complementary independent variable in the model. In this context Elliot and Rhodd (1999) and Vera (2006) inserted interest payments, Ferreira and Canuto (2003) inserted interest payments, dividends and profits, and Alleyne and Francis (2008) took into account interest payments and net transfers. In addition to interest payments, Moreno-Brid (2003) inserted the constant ratio of the current account deficit to income as a sustainability condition into the model by pointing out the limitations of the external debt accumulation. Within this literature only Elliot and Rhodd (1999) investigated Turkey alongside other sample countries.

Elliot and Rhodd (1999) tested and compared the debt-servicing incorporated version with the original and capital inflows extended versions of Thirlwall's Law, but the test results for the majority of the sample countries did not clearly support the inclusion of debt-servicing. The test results for Turkey were even more disappointing. The estimated output growth rate of Turkey for the original model and the capital flows incorporated model were $6.1 \%$ and $5.9 \%$ respectively against the actual output growth rate of $5.8 \%$. However, for the interest payments for the incorporated version, the estimated output growth rate was $2.2 \%$, which exhibits the highest deviation from the actual output growth rate (Elliot and Rhodd 1999: 1146). It is not possible to explain this failure with regards to the empirical application because of the absence of a detailed description of the test procedure, the data generation and the data definitions in their article. Nevertheless, it can be speculated that an inadequate definition of the import capacity generating components of $\mathrm{BOP}$ is one possible reason. In this context, a closer look at the $\mathrm{BOP}$ sheet reveals that the interest payments and earnings are displayed in the current account side under the primary investment debits and credits balance. Therefore, only taking into account the interest payments may cause a miscalculation of the contribution to the import capacity. In the current account balance under services and investments, in addition to interest payments, there are several different types of earnings and payments which affect the import capacity of a country. 
Erkin Bairam (1988, 1990, 1991, and 1993a) performed another group of applications. In all applications, Bairam tested the original Thirlwall's Law by using the linear regression method which is likely to cause spurious regression and forecasting errors due to the non-stationarity of the series. In his first attempt, Bairam (1988) estimated the import and export functions of 19 European and North American countries, including Turkey, to compute the BPCG rate of output. In this application he used annual data spanning from 1970 to 1985 by applying the Two-Stage Least Squares method. The estimated yearly average output growth of the original model for Turkey was $6.9 \%$, while the actual average output growth rate was $5 \%$, and according to Bairam the difference between them was quite small. Although he considered the findings satisfactory, he reasoned the deviation between the actual and estimated values by the measurement error and inaccuracy of the data. In his other paper Bairam (1993a) used the estimation results of his work in 1988.

\begin{tabular}{|c|c|c|c|c|c|c|c|c|}
\hline & Period & $x$ & $\Pi$ & $\gamma$ & $\mathrm{y}$ & $y^{*}$ & $y^{* *}$ & $\mathrm{y}^{\mathrm{i}}$ \\
\hline $\begin{array}{l}\text { Thirlwall and Hussain } \\
\text { (1982) }\end{array}$ & $60-73$ & 5.6 & 0.92 & $\begin{array}{l}- \\
0.50\end{array}$ & 5.8 & 6.1 & 5.9 & $\begin{array}{l}\mathrm{n} / \\
\mathrm{a}\end{array}$ \\
\hline Elliott and Rhodd (1999) & $60-73$ & 5.6 & 0.92 & 0.50 & 5.8 & 6.1 & $5.9^{1}$ & 2.2 \\
\hline Bairam (1988), (1993a) & $70-85$ & 18.5 & 2.68 & 3.75 & 5.0 & 6.9 & $\mathrm{n} / \mathrm{a}$ & $\mathrm{a}$ \\
\hline Bairam (1990), (1991) & $73-83$ & 20.7 & 4.1 & $\mathrm{n} / \mathrm{a}$ & 4.2 & 5.0 & $\mathrm{n} / \mathrm{a}$ & $\mathrm{a}$ \\
\hline
\end{tabular}

Note: Here $x$ is the export growth, $\pi$ is the income elasticity of import, $\gamma$ is the price elasticity of import, $y$ is the actual growth rate of output, $y^{*}$ is the estimated growth rate of output through the original Thirlwall's Law, $y^{* *}$ is the estimated growth rate of output through the capital inflows incorporated in Thirlwall's Law and $y^{i}$ is the estimated growth rate of output through the capital inflows and interest payments incorporated in Thirlwall's Law.

Bairam's (1990) second attempt was the application of the original Thirlwall's Law to the annual data of 15 developing countries, including Turkey, by employing the Ordinary Least Squares (OLS) method. He underlined the data availability, measurement problems and possible errors and difficulties beforehand. The test results for Turkey for the period 1973-1983 showed that the estimated growth rate of income via the original model was $5.0 \%$ and the actual average growth rate of income was $4.2 \%$. Bairam used the same estimation results for Turkey in his subsequent article which investigates 11 Asian countries for various periods spanning from 1961 to 1985 (Bairam 1991). His findings confirmed the predictive power of the original Thirlwall's Law. In his subsequent paper Bairam (1993b) pointed out the importance of the stationarity of the series used in the regression analysis. Although he 
confirmed that his earlier studies were still valid, this point is important because the non-stationary series may cause spurious regression which inevitably causes erroneous empirical estimations. During the last two decades, economists have been implementing the cointegration technique in the non-stationary variables in order to avoid misleading results of spurious regression; therefore in this study this technique is preferred.

\section{The NESI incorporated version of Thirlwall's Law}

As pointed out earlier, the basic contribution of the extended Thirlwall's Law is the inclusion of capital flows into the model, with a strong emphasis on its import capacity enhancing characteristic. Since the current account side of the BOP consists of export, import, capital inflows and NESI, this last component should be incorporated into the model as a complementary variable. Thus, the import capacity of a country would be computed more realistically as the sum of exports, capital inflows and NESI. On this logical ground, the new balance of payments identity is expressed as:

$P_{t} X_{t}+F_{t}+S_{t} \equiv P_{t}^{*} M_{t} E_{t}(1)$

where $P_{t}$ denotes export price index, $X_{t}$ denotes real export, $F_{t}$ is the capital flows measured in domestic currency, $S_{t}$ is NESI, $P_{t}^{*}$ is the price of imports expressed in terms of foreign currency, $M_{t}$ is real import, and $E_{t}$ is the nominal exchange rate which is measured in domestic currency. Expressing the identity as an equation in logarithmic form yields:

$\theta\left(p_{t}+x_{t}\right)+\alpha\left(f_{t}\right)+\lambda\left(s_{t}\right)=\left(p_{t}^{*}+m_{t}+e_{t}\right)$

where, $\theta$, $a$ and $\lambda$ represent the shares of export, capital inflows and NESI respectively in the entire import bill, and the other lowercase letters represent the rates of changes of the variables defined above. By definition, $\theta+\alpha+$ $\lambda=1$. Import and export functions are:

$$
\begin{aligned}
& M_{t}=Y_{t}^{\pi}\left(\frac{P_{t}^{*} E_{t}}{P_{t}}\right)^{\gamma} \\
& X_{t}=W_{t}^{\varepsilon}\left(\frac{P_{t}}{P_{t}^{*} E_{t}}\right)^{\eta}
\end{aligned}
$$

The logarithmic forms of the import and export functions are:

$m_{t}=\pi y_{t}+\gamma\left(p_{t}^{*}+e_{t}-p_{t}\right)$ 
$x_{t}=\varepsilon w_{t}+\eta\left(p_{t}-e_{t}-p_{t}^{*}\right)(6)$

In logarithmic terms, $x_{t}$ is real exports, $m_{t}$ is real imports, $e_{t}$ is nominal exchange rates, $p_{t}$ is domestic price, $p_{t}^{*}$ is foreign price, $w_{t}$ is world (or trade partners') real income, $y_{t}$ is domestic real income, $\eta<0$ and $\varepsilon>0$ are price and income elasticities of exports, and $\gamma<0$ and $\pi>0$ are price and income elasticities of imports respectively. Inserting equations (5) and (6) into equation (2) yields the general equation (7), incorporating capital flows and fluctuating long run real exchange rates:

${ }^{y_{t}} \frac{(\theta \eta+\gamma)\left(p_{t}-e_{t}-p_{t}^{*}\right)+\left(p_{t}-p_{t}^{*}-e_{t}\right)+\left(\theta \varepsilon w_{t}\right)+\alpha\left(f_{t}-p_{t}\right)+\lambda\left(s_{t}-p_{t}\right)}{\pi_{t}}$

Assuming insignificant price elasticities or constant real exchange rates in the long run implies $e_{t}+p_{t}^{*}=p_{t}$ and $\varepsilon w_{t}=x_{t}$ and yields:

$y_{t}^{* * *}=\frac{\theta x_{t}+\alpha\left(f_{t}-p_{t}\right)+\lambda\left(s_{t}-p_{t}\right)}{\pi_{t}}$

In this case, the economic growth of a country would turn out to be constrained by the ratio of the growth rate of real exports, real capital inflows and real NESI to the income elasticity of imports. Note that the lower income elasticity of import $\left(\pi_{t}\right)$ and higher income elasticity of export $\left(\varepsilon_{t}\right)$ are a reflection of the successful BOP performance of an economy. Moreover, this can be considered as an achievement of an economy specialising in competitive industries (Bairam 1990: 712).

To show the separate contribution of each component we can express equation (8) as:

$y_{t}^{* * *}=\frac{\theta x_{t}}{\pi_{t}}+\frac{\alpha\left(f_{t}-p_{t}\right)}{\pi_{t}}+\frac{\lambda\left(s_{t}-p_{t}\right)}{\pi_{t}}$

If we assume that the current account only consists of exports and imports and we therefore leave aside the NESI, we obtain the capital inflows extended version of Thirlwall's Law:

$y_{t}^{* *}=\frac{\theta x_{t}+\alpha\left(f_{t}-p_{t}\right)}{\pi_{t}}$

Then, if we assume that the current account side of the BOP does not comprise the NESI $(\lambda=0)$ and all import bills are covered by export earnings 
$(\theta=1)$, then the current account deficit is zero so there is no need for capital inflows $(\alpha=0)$ and we obtain the original Thirlwall's Law:

$y_{t}^{*}=x_{t} / \pi_{t}(11)$

\section{Empirical Tests}

\section{Data and Methodology}

As the initial step of the empirical procedure, income elasticity of imports $(\pi)$ is obtained from the estimated import function. Then the real values of the remaining variables in the above equations are constructed. Finally, Turkey's estimated BPCG rates, through the original, capital inflows incorporated and NESI incorporated versions of Thirlwall's Law, are computed through equations (9), (10) and (11) respectively. Note that the same income elasticity of import is used for all modifications of Thirlwall's Law for the period 2003Q1-2015Q3.

It is widely accepted theoretically that the import demand of a country depends on the level of real output and the relative common currency prices between trading partners (Houthakker and Magee 1969; Khan 1974; Goldstein and Khan 1985). ${ }^{3}$

$\ln \left(m_{t}\right)=\beta_{0}+\beta_{1} \ln \left(y_{t}\right)+\beta_{2} \ln \left(r x r_{t}\right)$

On this ground, the income and price elasticities of imports are obtained by the estimation of the import demand function shown above in logarithmic form. Here in level values, $m_{t}$ is real import, $y_{t}$ is real GDP, and $r \times r_{t}$ is real exchange rates. In the estimation of Turkey's import function the cointegration method is applied to the series LM (logarithmic level of real imports), LY (logarithmic level of real GDP) and LRXR (logarithmic level of real exchange rates). In the empirical estimation, generating the variables in logarithmic form allows imports to respond to any changes in the value of real GDP and real exchange rates in proportion. In addition, assuming the constant income and price elasticities for the whole period evades the problem of radical drops in the elasticities as import increases (Khan, 1974, pp.679-80).

\footnotetext{
${ }^{3}$ Even though Thirlwall's Law asserts that real exchange rates have a quantitatively insignificant role in determining the growth of trade flows, the value of the income elasticity of import should be taken from the estimated import demand function that comprises the real exchange rate variable because excluding the effect of relative prices is to assume what should be tested (McCombie, 1997, p.346).
} 


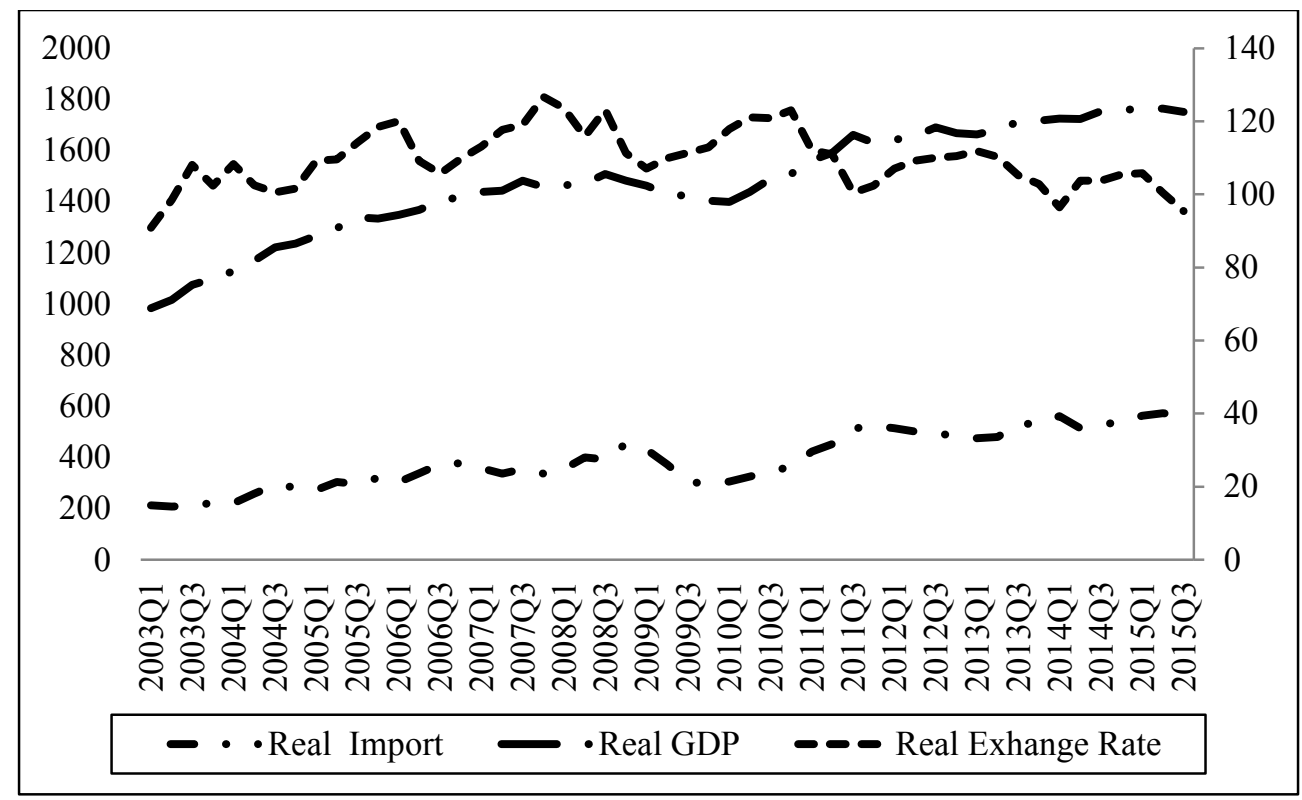

Figure 1: Real values of Gross Domestic Product, Exchange Rates and Imports for the Turkish Economy (2003Q1-2015Q3)

In this empirical application the main data source is the Central Bank of the Republic of Turkey (TCMB) and the Turkish Statistical Institute (TUIK). ${ }^{4}$ The capital flow variable is defined as the sum of the capital account, financial account, net error and omission and reserves. NESI is defined as the net earnings of services, primary and secondary investments. The quarterly growth rates of all components are computed as the difference in logarithmic values of the beginning and ending quarters of the period. However, Turkey's capital inflows are very unstable and volatile, which would cause incorrect computations of the growth rates through this method. Therefore, to get rid of very high negative values and high volatility, the moving average method is applied to the capital inflows data series.

\section{The Unit Root and Cointegration Tests}

In order to construct an appropriate model and to conduct the cointegration test, as an initial step, the estimation of the orders of integration are carried out through Phillips-Perron and ADF (augmented Dickey-Fuller test) unit

\footnotetext{
${ }^{4}$ The moving average of the quarterly level of GDP, export, import, capital flows and NESI are obtained from the TCMB BOP data set. The nominal values of these series are extracted in USD and multiplied by the USD/TL exchange rate to convert them into the TL. Then they are deflated by the Consumer Price Index (CPI 1995=100) to obtain their real values. The real exchange rate series is obtained from TCMB which is based on CPI $(1995=100)$ and computed for Turkey's 36 trade partners.
} 
root tests, but only the Phillips-Perron test results are displayed in Table $2 .{ }^{5}$ The test results reveal that $\mathrm{H}_{0}$ is accepted for the logarithmic level values of all series while $\mathrm{H}_{0}$ is rejected for the logarithmic $1^{\text {st }}$ difference of them. In other words, they are non-stationary in level and stationary in $1^{\text {st }}$ difference. The only variable is that LY exhibits stationarity in both level and $1^{\text {st }}$ difference under the assumption of the presence of intercept. Yet under the assumption of the presence of trend and intercept it is non-stationary in level and stationary in $1^{\text {st }}$ difference and the stationarity of all variables in the $1^{\text {st }}$ difference allows me to test the presence of one or more cointegrating relationships among them.

Table 2: Unit Root Test Results for the period 2003Q1- 2015Q3 with a 1\% significance level

\begin{tabular}{|c|c|c|c|c|c|c|}
\hline & \multicolumn{3}{|c|}{ Phillips-Perron (intercept) } & \multicolumn{3}{|c|}{$\begin{array}{l}\text { Phillip-Perron (trend and } \\
\text { intercept) }\end{array}$} \\
\hline & $\begin{array}{c}\text { Test } \\
\text { Statistic }\end{array}$ & $\begin{array}{c}\text { Crit. Val. } \\
(1 \%)\end{array}$ & Prob. & $\begin{array}{c}\text { Test } \\
\text { Statistic }\end{array}$ & $\begin{array}{c}\text { Crit. Val. } \\
(1 \%)\end{array}$ & Prob. \\
\hline LM level & -1.475769 & -3.568308 & 0.5376 & -2.338941 & -4.152511 & 0.4060 \\
\hline LM $1^{\text {st }}$ dif. & -5.727596 & -3.571310 & 0.0000 & -5.711520 & -4.156734 & 0.0001 \\
\hline LY level & -3.705585 & -3.568308 & 0.0069 & -3.188492 & -4.152511 & 0.0984 \\
\hline LY $1^{\text {st }}$ dif. & -4.771404 & -3.571310 & 0.0003 & -5.499485 & -4.156734 & 0.0002 \\
\hline LRXR level & -3.029478 & -3.568308 & 0.0389 & 0.100596 & -2.612033 & 0.7101 \\
\hline $\begin{array}{l}\text { LRXR } 1^{\text {st }} \\
\text { dif. }\end{array}$ & -6.936838 & -3.571310 & 0.0000 & -7.024203 & -2.613010 & 0.0000 \\
\hline
\end{tabular}

Test results for LRXR are extracted under the assumptions of intercept and no trendintercept.

If there were only two variables, the simplest technique for the cointegration test would be the Engle \& Granger (1987) method. ${ }^{6}$ However, there are more than two variables so the existence of more than one cointegration relationship is possible (Verbeek 2012: 358). This can be captured through the

\footnotetext{
${ }^{5}$ The ADF is the test procedure based on the approximation of an autoregressive-moving average model by an autoregression which is developed by Said and Dickey (1984). In this technique the general strategy is the inclusion of the lagged differences of the variable under consideration to make the error term asymptotically a white noise process. However, neither too many lags nor too few are desirable in general because this may lead to serious forecasting problems. As an alternative, Phillips and Perron (1988) have proposed an approach which adjusts the DF-statistics obtained by original Dickey-Fuller regression in order to take into account the potential autocorrelation pattern in the errors (Verbeek 2012: 296). Although only the Phillips Perron test results are displayed in Table 1, both methods are used and similar results are obtained in this application.

${ }^{6}$ The Engle-Granger method is simply the application of the unit root test on the residual obtained by OLS estimation of a regression equation. If the residual is stationary then the cointegration relationship exists between two variables.
} 
Johansen cointegration test procedure, which was developed by Johansen $(1988,1991)$ and Johansen and Juselius (1990 and 1992) as a multivariate method based on a Vector Autoregression (VAR) representation of the stochastic process. Therefore, initially the Vector Autoregressive (VAR) model was estimated with the optimal lag lengths and then the Johansen cointegration technique is applied to the data series.

Table 3: The determination of lag length of the VAR model according to lag order selection criteria

\begin{tabular}{ccccccc}
\hline Lag & LogL & LR & FPE & AIC & SC & HQ \\
\hline 0 & 164.9183 & NA & $2.04 \mathrm{e}-07$ & -6.890139 & -6.772044 & -6.845699 \\
1 & 295.4648 & 238.8725 & $1.16 \mathrm{e}-09$ & -12.06233 & $-11.58996^{*}$ & -11.88457 \\
2 & 310.8055 & $\mathbf{2 6 . 1 1 1 7 3 *}$ & $\mathbf{8 . 9 1 e - 1 0 *}$ & $\mathbf{- 1 2 . 3 3 2 1 5 *}$ & -11.50549 & $\mathbf{- 1 2 . 0 2 1 0 7 *}$ \\
3 & 313.3939 & 4.075386 & $1.19 \mathrm{e}-09$ & -12.05932 & -10.87837 & -11.61492 \\
4 & 319.7942 & 9.260050 & $1.36 \mathrm{e}-09$ & -11.94869 & -10.41346 & -11.37097 \\
\hline
\end{tabular}

Note: Here * indicates lag order selected by the criterion, LR: sequential modified LR test statistic (each test at the 5\% level), FPE: Final prediction error, AIC: Akaike information criterion, SC: Schwarz information criterion, HQ: Hannan-Quinn information criterion.

The optimal lag length is important in the cointegration technique because too few lags lead to the rejection of the null hypothesis immediately, while too many of them reduce the power of the test (Verbeek 2012: 360). According to the majority of E-views lag order selection criteria, the optimal significant lag length is 2 in this VAR model (see Table 3).

Table 4: VAR residual serial correlation LM test

\begin{tabular}{ccc}
\hline Lags & LM-Stat & Prob \\
\hline 1 & 22.11608 & 0.0085 \\
2 & 6.079574 & 0.7319 \\
3 & 10.74151 & 0.2938 \\
4 & 19.91197 & 0.0185 \\
\hline
\end{tabular}

${ }^{*}$ Null Hypothesis is no serial correlation in lag order $h$.

To test the sufficiency of the lag length, the serial correlation LM test is applied to the residual of the estimated VAR model. In general, it is suggested to start with the longest lag length and then shorten it by eliminating the insignificant lags (Enders 2004: 363). The smaller lag lengths are 1 and 2 but as shown in Table 4, the probability value of lag 1 is less than 0.05 , thus we reject the null hypothesis and accept the presence of serial correlation in the residual at the $95 \%$ significance level. Whereas for lag 2 the probability value is higher than 0.05 , therefore we accept the null hypothesis and reject the 
presence of serial correlation in residual at the $95 \%$ significance level. Therefore, the determined lag length is 2 and it is statistically sufficient.

Table 5: Testing the stability of the system by examining the complex roots through the AR roots test

\begin{tabular}{ll}
\hline 0.954895 & 0.954895 \\
$0.593301-0.453224 \mathrm{i}$ & 0.746604 \\
$0.593301+0.453224 \mathrm{i}$ & 0.746604 \\
0.724216 & 0.724216 \\
$-0.173494-0.079976 \mathrm{i}$ & 0.191040 \\
$-0.173494+0.079976 \mathrm{i}$ & 0.191040 \\
\hline
\end{tabular}

Then the complex roots of the VAR model are tested to examine the stability of the system. Since all values of the modules are less than unity, (in table 5 all the modules are less than 1 so the expression is fine) no root lies outside the unit circle. Then the VAR satisfies the stability condition (see Table 5).

\begin{tabular}{cccc}
\hline Table 6: VAR residual normality test results & & \\
\hline Component & Jarque-Bera & Df & Prob. \\
\hline 1 & 0.488334 & 2 & 0.7834 \\
2 & 0.323304 & 2 & 0.8507 \\
3 & 0.713979 & 2 & 0.6998 \\
\hline Joint & 1.525617 & 6 & 0.9578 \\
\hline
\end{tabular}

The last procedure is the normality test before applying the Johansen cointegration technique. As shown in Table 6, the probability values are higher than the 0.05 significance level and we accept the null hypothesis that residuals are multivariate normal and reject the presence of non-normality at the $95 \%$ significance level.

Lastly, the Johansen Cointegration technique is applied to the estimated VAR (2) model to detect a cointegration relation among the variables (see Table 7). The estimation results reveal (for $\mathrm{H}_{0}: \mathrm{r}=0$ and $\mathrm{H}_{1}: \mathrm{r}=1$ ) that the cointegration trace test and the max-eigenvalue test statistics are higher than their $5 \%$ test critical values simultaneously, so the null hypothesis of no cointegration is rejected and the presence of at least one cointegration vector among variables is accepted at the $95 \%$ significance level. On the other hand, we accept the null hypothesis (for $\mathrm{H}_{0}: \mathrm{r} \leq 1 \mathrm{H}_{1}: \mathrm{r}=2$ and $\mathrm{H}_{0}: \mathrm{r} \leq 2 \mathrm{H}_{1}: \mathrm{r}=3$ ) and reject the presence of two or three cointegration relations since the trace test and maxeigenvalue test statistics are lower than their $5 \%$ test critical values. 


\begin{tabular}{ccccccc}
\hline \multicolumn{6}{c}{ Table 7: Johansen Cointegration Test Results for the period 2003Q1- 2015Q3 } \\
\hline Number of & Trace & Crit. Val. & Prob. & Max. & Crit. & Prob. \\
\hline $\mathrm{H}_{0}: \mathrm{r}=0 \mathrm{H}_{1}: \mathrm{r}=$ & $\mathbf{4 5 . 0 8 4 8 9}$ & 35.19275 & 0.0032 & $\mathbf{2 7 . 1 0 8 7 8}$ & 22.29962 & $\mathbf{0 . 0 0 9 9}$ \\
$\mathrm{H}_{0}: \mathrm{r} \leq 1 \mathrm{H}_{1}: \mathrm{r}=$ & $\mathbf{1 7 . 9 7 6 1 1}$ & $\mathbf{2 0 . 2 6 1 8 4}$ & 0.1001 & $\mathbf{1 4 . 7 2 8 4 4}$ & $\mathbf{1 5 . 8 9 2 1 0}$ & $\mathbf{0 . 0 7 5 4}$ \\
$\mathrm{H}_{0}: \mathrm{r} \leq 2 \mathrm{H}_{1}: \mathrm{r}=$ & 3.247678 & 9.164546 & 0.5354 & 3.247678 & 9.164546 & 0.5354 \\
\hline
\end{tabular}

So there is only one cointegration relation for the period 2003Q1- 2015Q3 and the estimated normalised cointegration equation is:

LM= 1.854 LY - 0.472 LRXR - 5.354

As seen in the equation above, the estimated income elasticity of imports has a positive sign and is higher than unity. The income elasticity of imports in this period is 1.854 . The price elasticity of imports is 0.472 and has correct sign, negative but it is negligible. These results reveal that a $1 \%$ increase in the real GDP (Y) causes a 1.854\% increase in the demand for import goods and a $1 \%$ increase in real exchange rates (RXR) causes a $0.472 \%$ decrease in the demand for import goods. These results are quite consistent with the model expectations and the economic theory.

\section{Evaluation of Turkey's Economic Growth and BOP Performance}

\section{The Presentation of Turkey's Computed BPCG Rates and their Sub- Components}

In this section, Turkey's computed BPCG rates are presented, according to the illustrated definitions of the original $\left(\mathrm{y}^{*}\right)$, capital inflows incorporated $\left(y^{* *}\right)$ and NESI incorporated versions $\left(y^{* * *}\right)$ of Thirlwall's Law (see Table 8$) .^{7}$ In addition, the contributions of all introduced components in NESI incorporated Thirlwall's Law, such as exports, capital inflows and NESI are computed separately according to equation (9), (see Table 9).

\begin{tabular}{|c|c|c|}
\hline & $\begin{array}{c}\text { Quarterly } \\
(\%)\end{array}$ & $\begin{array}{c}\text { Yearly } \\
(\%)\end{array}$ \\
\hline Estimated BPCG of the Original Model $\left(\mathrm{y}^{*}\right)$ & 0.646 & 2.582 \\
\hline Estimated BPCG of the Capital Inflows Extended Model & 1.094 & 4.374 \\
\hline NESI Incorporated BPCG $\left(\mathrm{y}^{* * *}\right)$ & 1.147 & 4.586 \\
\hline Actual Average GDP Growth (y) & 1.132 & 4.528 \\
\hline
\end{tabular}

Note: Turkey's yearly average real GDP growth rate is $6.5 \%$ for the period 1960-2000.

\footnotetext{
${ }^{7}$ In Tables 8 and 9 except for the income elasticity of import all quarterly variables are computed by the author according to the definitions explained in section 4.
} 
First of all, computed yearly average BPCG rates through the original and capital inflows extended Thirlwall's Laws are $\mathrm{y}^{*}=2.58 \%$ and $\mathrm{y}^{* *}=4.37 \%$ respectively (see Table 8). Due to the insufficiencies of these modifications, these rates are significantly smaller than the actual yearly average GDP growth rate; $\mathrm{y}=4.53 \%$. On the other hand, the computed yearly average BPCG rate through the NESI incorporated version is $\mathrm{y}^{* * *}=4.59 \%$ and this is the closest estimation to the actual GDP growth rate. The negligible numerical deviation (which is approximately $0.06 \%$ ) between estimated yearly average BPCG rate (through the NESI incorporated version) and actual yearly average GDP growth rate might be explained by the real exchange rate movements which has a $0.47 \%$ negative effect on the demand for import goods. On the basis of this evidence it can be concluded that the NESI incorporated version of Thirlwall's Law is remarkably robust for Turkey's data for the period of 2003Q1-2015Q3.

Table 9: Shares, average growth rates and contribution of exports, capital flows and NESI to Turkey's average BPCG rate for the period 2003Q1-2015Q3

\begin{tabular}{|c|c|c|c|c|c|}
\hline $\begin{array}{l}\text { BOP } \\
\text { Components } \\
\text { in the BPCG }\end{array}$ & $\begin{array}{c}\text { Average } \\
\text { Quarterl } \\
\text { y } \\
\text { Growth } \\
\text { Rate (\%) } \\
\end{array}$ & $\begin{array}{c}\text { Shares } \\
\text { in Total } \\
\text { Import } \\
\text { Bills } \\
(\%) \\
\end{array}$ & $\begin{array}{c}\text { Estimate } \\
\text { d Income } \\
\text { Elasticity } \\
\text { of } \\
\text { Import } \\
(0 / 0)\end{array}$ & $\begin{array}{l}\text { Quarterly } \\
\text { Average } \\
\text { Contributio } \\
\text { n to the } \\
\text { BPCG } \\
(0 / 0)\end{array}$ & $\begin{array}{c}\text { Yearly } \\
\text { Average } \\
\text { Contributio } \\
\text { n to the } \\
\text { BPCG (\%) }\end{array}$ \\
\hline \multicolumn{6}{|c|}{ Disaggregation } \\
\hline Exports & 1.657 & 72.21 & 1.854 & 0.646 & 2.582 \\
\hline Capital Inflows & 4.094 & 20.28 & 1.854 & 0.448 & 1.792 \\
\hline NESI & 1.312 & 0.749 & 1.854 & 0.053 & 0.212 \\
\hline Total $\left(\mathrm{y}^{* * *}\right)$ & - & 100 & - & 1.147 & 4.586 \\
\hline
\end{tabular}

Secondly, the contribution of BOP components to Turkey's average BPCG rate, which is computed according to equation (9), is shown in Table 9. The yearly average contribution of exports, capital inflows and NESI are $2.6 \%$, $1.8 \%$ and $0.2 \%$ respectively for the period of 2003Q1-2015Q3. Leaving aside the income elasticity of imports, the magnitude of these numbers is the direct result of both the growth rates of these components and their shares in the total import bills. The yearly average shares of exports, capital inflows and NESI in the total import bills are $72.2 \%, 20.3 \%$ and $0.75 \%$ respectively. The growth rates of them, for the period investigated, are 1.7\%, $4.1 \%$ and $1.3 \%$ respectively. Although the share of exports is much higher than the share of capital inflows in import bills, their contributions to the average BPCG rate does not reflect this remarkable difference, due to the opposite tendency in their growth rates. Finally, although it has the smallest average share and 
smallest growth rate, the share of NESI in total import bills is significant and should not be neglected.

\section{Turkey's BOP and GDP Growth Performance}

After the 2001 crisis, as in previous stabilization programs, Turkey implemented contractionary monetary and fiscal policies with strong external anchors, such as the IMF program and the EU membership process, to re-establish macroeconomic stability. The implicit inflation targeting (IT) was implemented between 2002 and 2005 as a monetary policy, and then it shifted to the explicit IT. The complementary elements of the stabilization program were banking sector regulations, supplementary foreign trade liberalization, further privatisation and the labour market regulations in favour of business.

The extensive economic and social restructurings after the 2001 crisis brought about increases in labour productivity, capacity utilization and capital inflows. In the first half of the period 2003-2015 Turkey achieved $6.3 \%$ average GDP growth rate but this could not be sustained in the second half because of the lack of comprehensive industrial and technological policies to further increase industrial production and competitiveness. In the second half of the same period the average GDP growth rate was $2.8 \%$ which indicates the end of the 2003-2015 boom-bust cycles. Turkey's actual yearly average real GDP growth rate was $4.5 \%$ for the period investigated.

These observations are consistent with empirical results and demonstrate that Turkey's poor BOP performance played an important role as a constraint on overall real GDP growth for the period investigated and it needed to be improved to achieve a real GDP growth rate around its long-term average (6.5\% for the period 1960-2000). The current evidence suggest that contrary to its ELG policy goals, due to the lack of competitiveness of the export sectors, Turkey still has a very high level of trade deficit and needs steady and sufficient level of capital inflows to offset its chronic trade deficit. Despite having a high share in the import bills (72\%), the quarterly average growth rate of exports $(1.7 \%)$ is far below the quarterly average growth rate of capital inflows $(4.1 \%)$ in the period investigated. Although real exchange rates are not the fundamental determinant in Turkey's trade balance, it can still be argued that, during the period 2003Q1-2015Q3, the low exchange rates and high interest rates worsened the situation by further decelerating the exports and accelerating the imports and capital inflows in Turkey. This was an inevitable consequence of the IT monetary policy strategy. 


\begin{tabular}{|c|c|c|c|c|c|c|c|}
\hline & $\begin{array}{l}\text { Tot. } \\
\text { For. } \\
\text { Debt } \\
\text { (bil. } \\
\text { USD) }\end{array}$ & $\begin{array}{l}\text { Tot. } \\
\text { For. } \\
\text { Debt/ } \\
\text { GDP }\end{array}$ & $\begin{array}{c}\text { Short- } \\
\text { Term For. } \\
\text { Debt } \\
\text { (bil. USD) }\end{array}$ & $\begin{array}{l}\text { Short- } \\
\text { Term } \\
\text { For. } \\
\text { Debt/ } \\
\text { GDP }\end{array}$ & $\begin{array}{c}\text { Long- } \\
\text { Term } \\
\text { For. Debt } \\
\text { (bil. USD) }\end{array}$ & $\begin{array}{l}\text { Long- } \\
\text { Term For. } \\
\text { Debt/ } \\
\text { GDP }\end{array}$ & $\begin{array}{c}\text { Short- } \\
\text { Term } \\
\text { For. } \\
\text { Debt / } \\
\text { Total } \\
\text { Res. }\end{array}$ \\
\hline 2003 & 144.16 & 0.48 & 23.01 & 0.08 & 121.15 & 0.40 & 0.68 \\
\hline 2004 & 161.14 & 0.40 & 32.20 & 0.08 & 128.94 & 0.32 & 0.89 \\
\hline 2005 & 170.75 & 0.34 & 38.91 & 0.08 & 131.84 & 0.26 & 0.77 \\
\hline 2006 & 208.11 & 0.38 & 42.85 & 0.08 & 165.26 & 0.31 & 0.70 \\
\hline 2007 & 250.01 & 0.39 & 43.15 & 0.07 & 206.87 & 0.32 & 0.61 \\
\hline 2008 & 280.96 & 0.38 & 52.52 & 0.07 & 228.44 & 0.31 & 0.75 \\
\hline 2009 & 268.96 & 0.42 & 48.99 & 0.08 & 219.97 & 0.35 & 0.70 \\
\hline 2010 & 292.06 & 0.40 & 77.25 & 0.11 & 214.81 & 0.29 & 0.96 \\
\hline 2011 & 303.93 & 0.40 & 81.58 & 0.11 & 222.35 & 0.29 & 1.04 \\
\hline 2012 & 339.04 & 0.43 & 100.20 & 0.13 & 238.85 & 0.30 & 1.00 \\
\hline 2013 & 389.15 & 0.47 & 130.42 & 0.16 & 258.73 & 0.31 & 1.16 \\
\hline 2014 & 402.72 & 0.51 & 132.89 & 0.17 & 269.83 & 0.34 & 1.25 \\
\hline 2015 & 405.22 & 0.49 & 127.50 & 0.15 & 277.72 & 0.34 & 1.29 \\
\hline
\end{tabular}

Moreover, Turkey's poor export performance shows the growing tendency of the economy to finance its external deficit with capital inflows. The consensus among the majority of economists is that having such a chronic and high level of trade deficit, which is financed by foreign capital inflows, causes foreign debt accumulation and cannot be sustained in the long run. It increases the indebtedness and maturity shortening of the economy. Indeed, during the period 2003Q1-2015Q3 Turkey's total foreign debt increased from 144.162 billion to 405.223 billion USD (see Table 10). In addition, the maturity shortening arose as an outcome of the increasing financial fragility. The ratio of short-term debt to GDP was $15 \%$ in 2015 while it was $8 \%$ at the beginning of the period (see Table 8). Another indicator is the ratio of short-term foreign debt to reserves which has been increasing since mid-2009, but until 2013 it was under 100\%; however since 2013 it has been over $100 \%$ and in 2015 it was $129 \%$ (see Table 10). The two latter ratios are regarded as a signal of financial crisis by the majority of economists. Also, a kind of self-fulfilling relationship started to crystallize between financial fragility and debt maturity shortening. Financial fragility increased further because of this worsening structure of debt during this period. 


\section{Conclusion}

In the neoliberal era, contrary to the ELG policy goal of sustainable and rapid economic growth without persistent external imbalances, Turkey's economic growth was increasingly destabilized by boom-and-bust cycles that were mainly caused by poor foreign trade performance and highly unstable capital movements. As a manifestation of the contradicting tendencies of the output growth and BOP performance, Turkey could not reach a GDP growth rate higher than its long-term historical average in this neoliberal era and the poor GDP growth performance persisted during the period 2003-2015.

This paper investigated the relationship between GDP growth rate and BOP performance through the NESI incorporated version of Thirlwall's Law, which allows for the contribution of NESI to the estimated BPCG rate of the Turkish economy. The test results are consistent with Turkey's economic realities. Turkey's poor foreign trade performance remains a main constraint on economic growth and accelerates its foreign debt accumulation in the period investigated. The computed growth rates indicate that the NESI incorporated version of Thirlwall's Law is robust and separately computed contributions of the model's components, such as export, capital inflows and NESI, correspond with Turkey's observed economic realities.

Considering the empirical evidence and statistical data it can be concluded that, in the period 2003-2015, Turkey received a significant amount of foreign capital inflows as a result of both slowdown in the major economies and its post-2001 economic crisis reforms. Through these developments Turkey achieved a long-term growth path without any deep fluctuations in the macroeconomic fundamentals in the first half of the period 2003-2015. However, it could not benefit from this advantageous position to conduct comprehensive industrial and technological policies to develop a high valueadded, sophisticated and capital-intensive export goods sector which would eventually increase the competitiveness of the economy and solve the chronic external deficit problem.

\section{References}

Alleyne, D., and Francis A. A. (2008) Balance of Payments Constrained Growth in Developing Countries: A Theoretical Perspective, Metroeconomica, 59(2): 189-202.

Alonso, J., and Garcimartin, C. (1998) A new approach to balance-ofpayments constraint: Some empirical evidence, Journal of Post Keynesian Economics, 21(2): 259-82. 
Alonso, J. A. (1999) Growth and the External Constraint: Lessons from the Spanish Case, Applied Economics, 31: 245-53.

Bairam, E. (1988) Balance of payments, the Harrod foreign trade multiplier and economic growth: the European and North American experience, 197085, Applied Economics, 20: 1635-1642.

Bairam, E. (1990) The Harrod foreign trade multiplier revisited, Applied Economics, 22, 711-718.

Bairam, E. (1993a) Income elasticities of exports and imports: a reexamination of the empirical evidence, Applied Economics, 25: 71-74.

Bairam, E. (1993b) Static versus dynamic specifications and the Harrod foreign trade multiplier, Applied Economics, 25: 739-742.

Bairam, E. and Dempster, G. J. (1991) The Harrod foreign trade multiplier and economic growth in Asian countries, Applied Economics, 23: 1719-1724.

Crafts, N. (1988a) The assessment: British economic growth over the long run, Oxford Review of Economic Policy, 4(1): i-xxi.

Crafts, N. (1988b) British economic growth before and after 1979: a review of the evidence, Centre for Economic Policy Research.

Crafts, N. (1993) Can Deindustrialisation Seriously Damage Your Wealth? A Review of why Growth Rates Differ and how to Improve Economic Performance, London; Institute of Economic Affairs.

Elliot, D. and Rhodd, R. (1999) Explaining growth rate differences in highly indebted countries: an extension to Thirlwall and Hussain, Applied Economics, 31: 1145-1148.

Enders, Walter. (2004) Applied Econometric Time Series, Second Edition, John Wiley \& Sons; USA.

Engle, R. F. and Granger, C. W. J. (1987) Cointegration and Error Correction: Representation, Estimation and Testing, Econometrica, 55(2): 251-76.

Ferreira, A. and Canuto, O. (2003) Thirlwall's Law and Foreign Capital in Brazil, Momento Economico, 125: 18-29.

Goldstein, M. and M. S., Khan. (1985) Income and Price Effects in Foreign Trade, in R. W. Jones and P. B. Kenen (eds.) Handbook of International Economics (Vol. II), Elsevier Science Publications, New York, 1041-1105. 
Harrod, R. (1933) International Economics, Cambridge University Press, Cambridge.

Houthakker, H. and Magee, S. (1969) Income and Price Elasticities in World Trade, Review of Economics and Statistics, 51(2): 111-125.

Johansen, S. (1988) Statistical Analysis of Cointegrating Vectors, Journal of Economic Dynamics and Control, 12(2-3): 231-54.

Johansen, S. (1991) Estimation and Hypothesis Testing of Cointegrating Vectors in Gaussian Vector Autoregressive Models, Econometrica, 59(6): 155180 .

Johansen, S. and Juselius, K. (1990) Maximum Likelihood Estimation and Interference on Cointegration with Applications to the Demand for Money, Oxford Bulletin of Economics and Statistics, 52(2): 169-210.

Johansen, S. \& Juselius, K. (1992) Testing Structural Hypothesis in a Multivariate Cointegration Analysis of the PPP and the UIP for UK, Journal of Econometrics, 53: 211-44.

Kaldor, N. (1966) Causes of the Slow Rate of Economic Growth of the United Kingdom, Cambridge University Press, Cambridge.

Kaldor, N. (1970) The Case for Regional Policies, Scottish Journal of Political Economy, 17: 337-348.

Khan, M. S. (1974) Import and Export Demand in Developing Countries, I.M.F. Staff Papers, 21(3): 678-693.

McCombie, J. (1985), Economic Growth, Harrod Foreign Trade Multiplier, and the Hicks' Super Multiplier, Applied Economics, 17: 55-72.

McCombie, J. (1989) Thirlwall's Law' and balance of payments constrained growth - a comment on the debate, Applied Economics, 21: 611-29.

McCombie, J. (1997) On the Empirics of Balance of Payments Constrained Growth, Journal of Post Keynesian Economics, 19 (3): 345-375.

McCombie, J. and Thirlwall, A. P. (1997) The Dynamic Harrod Foreign Trade Multiplier and the Demand-orientated Approach to Economic Growth: an evaluation, International Review of Applied Economics, 11(1): 5-26.

McGregor, P. G., and Swales, J. K. (1985) Professor Thirlwall and Balance of Payment Constrained Growth, Applied Economics, 17 (5): 17-32. 
McGregor, P. G. \& Swales, J. K. (1986) “Balance of payments constrained growth: a rejoinder to Professor Thirlwall" Applied Economics, 18 (12): 12651274 .

McGregor, P. G. \& Swales, J. K. (1991) Thirlwall's Law and balance of payments constrained growth: further comment on the debate, Applied Economics, 23(1): 9-20.

Moreno-Brid, J. C. (2003) Capital Flows, Interest Payments and the Balance of Payments Constrained Growth Model: A Theoretical and Empirical Analysis, Metroeconomica, 54(2-3): 346-365.

Phillips, P. C. B. and Perron, P. (1988) Testing for a Unit Root in Time Series Regression, Biometrika, 75(2): 335-346.

Said, S. E. and Dickey, D. A. (1984) Testing for Unit Roots in Autoregressive Moving Average Models of Unknown Order, Biometrika, 71(3): 599-607.

Santos-Paulino, Amelia and Thirlwall, A. P. (2004) The Impact of Trade Liberalisation on Exports, Imports and the Balance of Payments of Developing Countries, The Economic Journal, 114 (493): F50-F72.

Thirlwall, A. P. (1979) The Balance of Payments Constraint as an Explanation for International Growth Rate Differences, Banca Nazionale del Lavoro Quarterly Review, 32 (128): 45-53.

Thirlwall, A. P. and Hussain, M. Nureldin (1982) The Balance of Payments Constraint, Capital Flows and Growth Rate Differences between Developing Countries, Oxford Economic Papers, 34(3): 498-510.

Thirlwall, A. P. (1997) Reflections on the Concept of Balance-of-PaymentsConstrained Growth, Journal of Post Keynesian Economics, 19(3): 377-385.

Thirlwall, A. P. (2013) Economic Growth in an Open Developing Economy: The Role of Structure and Demand, Edward Elgar, Cheltenham.

Vera, L. A. (2006) The Balance of Payments Constrained Growth Model: A North-South Approach, Journal of Post Keynesian Economics, 29(1): 67-92.

Verbeek, Marno. (2012) A Guide to Modern Econometrics, Wiley Publication, West Sussex.

Verdoorn, P. J. (1949) Factors that Determine the Growth of Labour Productivity, in Italian Economic Papers, L. Pasinetti (ed.), Vol. II, Oxford: Oxford University Press. 